\title{
LONG-TERM STUDIES ABOUT ORTHOSTATIC TRAINING AFTER HIGH SPINAL CORD INJURY
}

\author{
By P. ENGEL and G. HildebrandT \\ Institut für Arbeitsphysiologie and Rehabilitationsforschung der Universität Marburg/Lahn, \\ W.-Germany (Dir.: Prof. Dr G. Hildebrandt)
}

IN the early stage of rehabilitation for physically handicapped people (paraplegics) the orthostatic way of testing the stability of the circulatory system is a very important item (Rieckert, 1970, 1972), as the orthostatic capacity, after a long period of lying, is considerably reduced in most cases because of the complete lack of movement and may impede their rehabilitation (Miller et al., I964).

By the systematic experiments with the tilting-table, in the way they are normally carried out for patients with spinal cord injuries that have just been treated, with the purpose of a therapy to stabilise circulation the efficiency of orthostatic regulations can be well observed by continually measuring the pulserate and the blood-pressure.

At the beginning, two groups of patients with traumatic spinal cord injury with lesions in upper or lower positions were compared, at the end of their clinical treatment, with a group of healthy persons by just one orthostatic experiment with the tilting table. All tested persons were continuously raised up to $80^{\circ}$, in steps of $20^{\circ}$ each, and lowered again in the same way. Measurements were taken in the third and last minute for each tilting angle.

In Figure I the average course of systolic and diastolic blood-pressure and the pulse-rate of a group of healthy persons can be seen in comparison with those of nine patients with spinal cord injuries in the cervical and the upper thorax area of the spine. The remarkable drop in the systolic blood-pressure with the paraplegics in connection with a diminuation of the pressure amplitude by this passive orthostatic strain shows the insufficient capacity for orthostatic regulation, which cannot be sufficiently compensated by the only inconsiderable rise of the pulse-rate. However, a considerably more stable capacity for orthostatic regulation is noticed in patients with localised spinal cord injury in the lower spine (below Th VI) as Figure 2 shows by the graph of another group of 13 paraplegics with lesions below Th VI in comparison with the previously considered group with lesions in upper parts of the spine. The group with lesions in the lower parts, at the end of their clinical (orthostatic) training, reacts in the same way as the group of healthy persons. For cases of injuries in the upper spinal cord, Jaeger-Denavit and Grossiord (I972) have already pointed out that such patients stay orthostatically insufficient even after a long period of training.

Conversely only one test of orthostatic regulation at this stage of rehabilitation with high strain on the circulatory system naturally reveals very little and illustrates only a glimpse of the process of rehabilitation. For a more detailed explanation of why patients with injuries in the upper spinal cord show such different reactions in the course of orthostatic training, we began to carry out long-term studies along with the treatments by the tilting table carried out several times a week.

To get to simple instructive data for the orthostatic behaviour we measured 

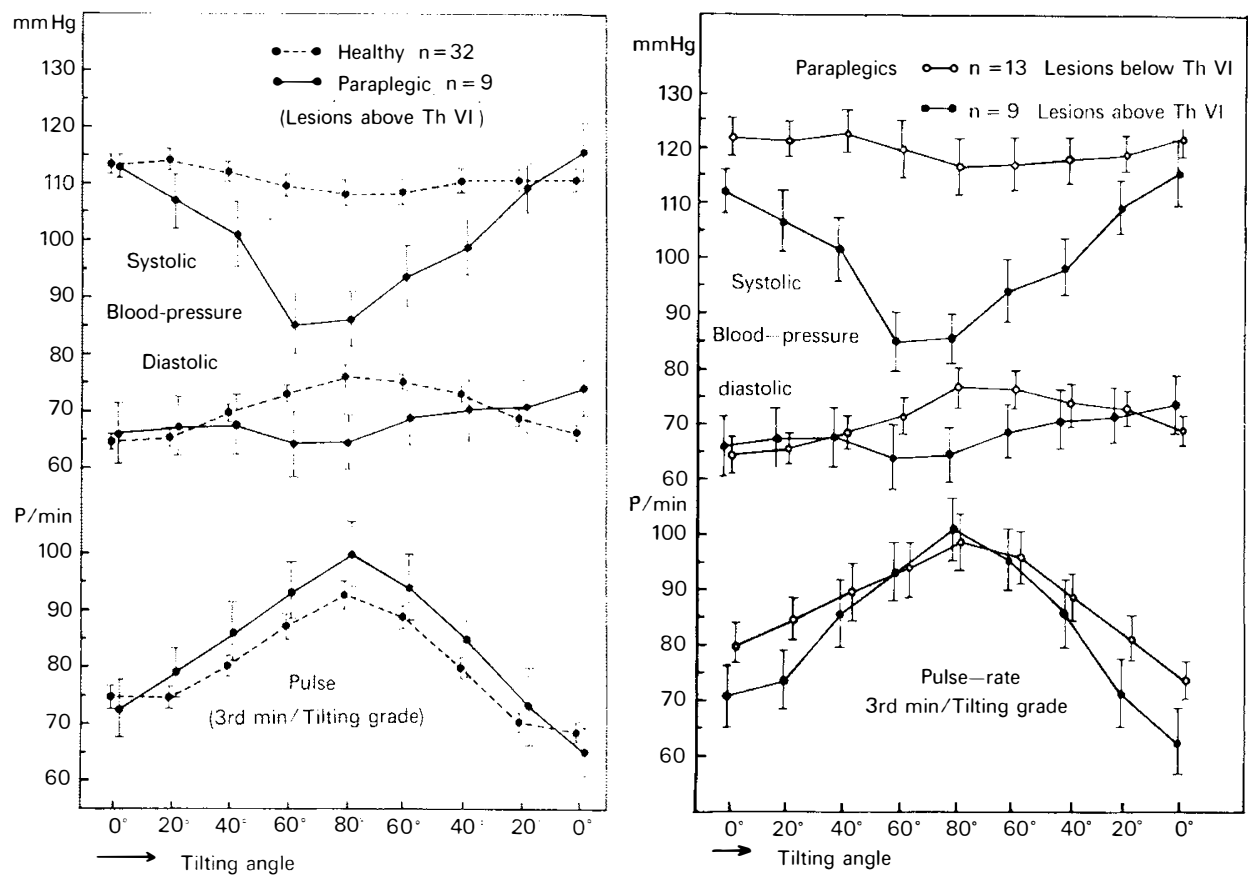

FIG. I (left)

Average course of systolic and diastolic blood-pressure and pulse-rate of a group of nine patients with high spinal cord injury in a single orthostatic tilt-table exercise at the end of their clinical treatment in comparison with a group of healthy persons. All tested persons were continuously raised to $80^{\circ}$, in steps of $20^{\circ}$ each, and lowered again in the same way. Measurements were taken in the third and last minute for each tilting angle. Braces indicate the range of standard error.

Fig. 2 (right)

Average course of a systolic and diastolic blood-pressure and the pulse-rate of two groups of paraplegics with localised spinal cord injury respectively above and below 6th thoracic vertebra in just one orthostatic tilt-table exercise at the end of their clinical treatment.

Method corresponding to Figure I. Braces indicate the range of standard error.

for the four steps of rising only the regression coefficient, that is the trend of pulse-rate increase and the diastolic and systolic blood pressure.

Figure 3 shows the sequence of weekly averages of our instructive data for four patients with injuries in the upper spinal cord, patients that we could test for at least 7 weeks without interruptions from the beginning of the tilting training. We found that the regression coefficient of the pulse-rate increase with tilting amounted to 13 per cent increase per $20^{\circ}$ of rising. In the course of 7 weeks there were no significant improvements. Even the pulse-rate at rest and the pulserate respiration ratio were hardly influenced. Only the rate of decrease in the systolic and diastolic blood-pressure became slightly smaller in the course of the last three weeks of training.

Figure 4 shows the average course of the regression coefficients of the pulserate increase in the four patients with spinal cord injuries in upper positions. You find lasting and often significant periodic fluctuations in the amount of pulse- 


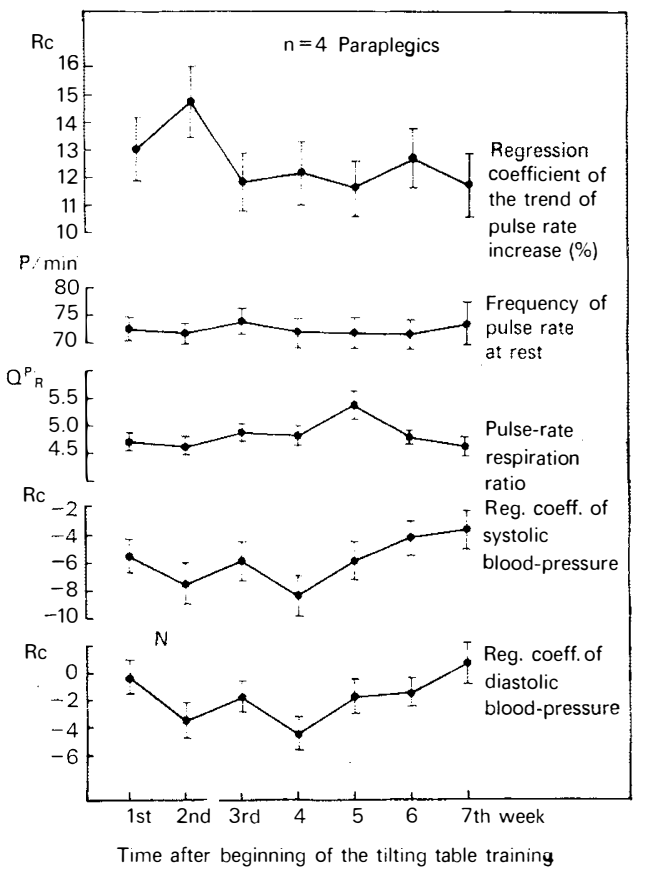

FIG. 3

Average course of the sequence of weekly averages for the regression coefficient of the pulserate and blood-pressure increase-per $20^{\circ}$ of raising-for four patients with lesions in the upper spinal cord (above Th VI) during orthostatic tilt-table exercise over a period of 7 weeks. In the middle of the figure average course of the weekly data of absolute pulse-rate and pulse-rate respiration ratio are shown. Braces indicate the range of standard error.

rate increase, the amplitude of which even increases from the first week to the second.

After the existing experiences with such reaction fluctuations in the course of adaptation processes, the inadequate damping of the patients with spinal cord injuries in upper positions must be seen as a sign for the lack of a stable success of adaptation (Hildebrandt, 1962, 1972; Engel \& Hildebrandt, 1973). It was revealed in a particularly significant way with an individual case, which we were able to continually examine for 55 days, that this inadequate damping of the periodic fluctuations in reaction is not limited in time. Figure 5 demonstrates the course of the absolute pulse-rate of this patient at the various tilting grades. It makes it clear that along with a rising crisis in regulation around the 2oth day of training an even higher crisis-like instability of orthostatic regulation was experienced even after the 4oth day of training. Thus one may deduct remarkable differences in the kinetics of adaption depending on the height of lesions in the spinal cord.

Whether the inadequate capacity for adaption with patients with spinal cord injuries in upper positions applies especially to orthostatic regulation only or even includes other regulatory systems still has to be found out by systematic research.

In spite of the small range of our existing experiences they may already prove that any meaningful prognosis of the way of rehabilitation necessarily depends 


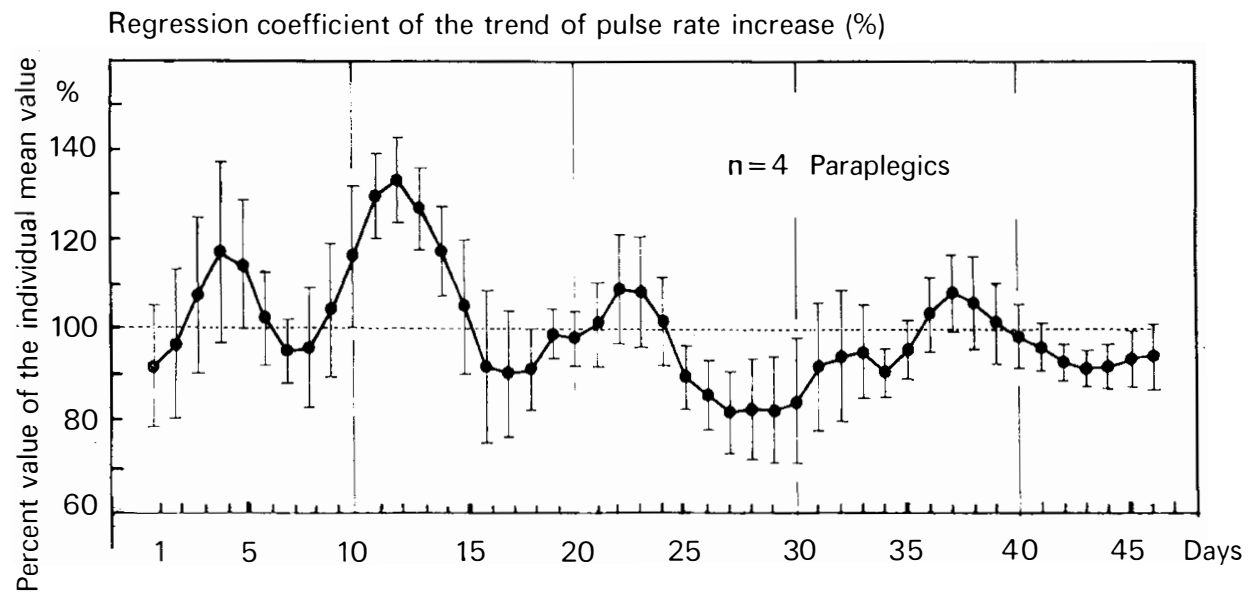

Time after beginning of the tilting table training

FIG. 4

Average course of regression coefficient of the pulse-rate increase-per $20^{\circ}$ of raisingduring daily orthostatic tilt-table exercise for four paraplegics with injuries in the upper spinal cord (above Th VI) over a period of 7 weeks. Braces indicate the range of standard error.

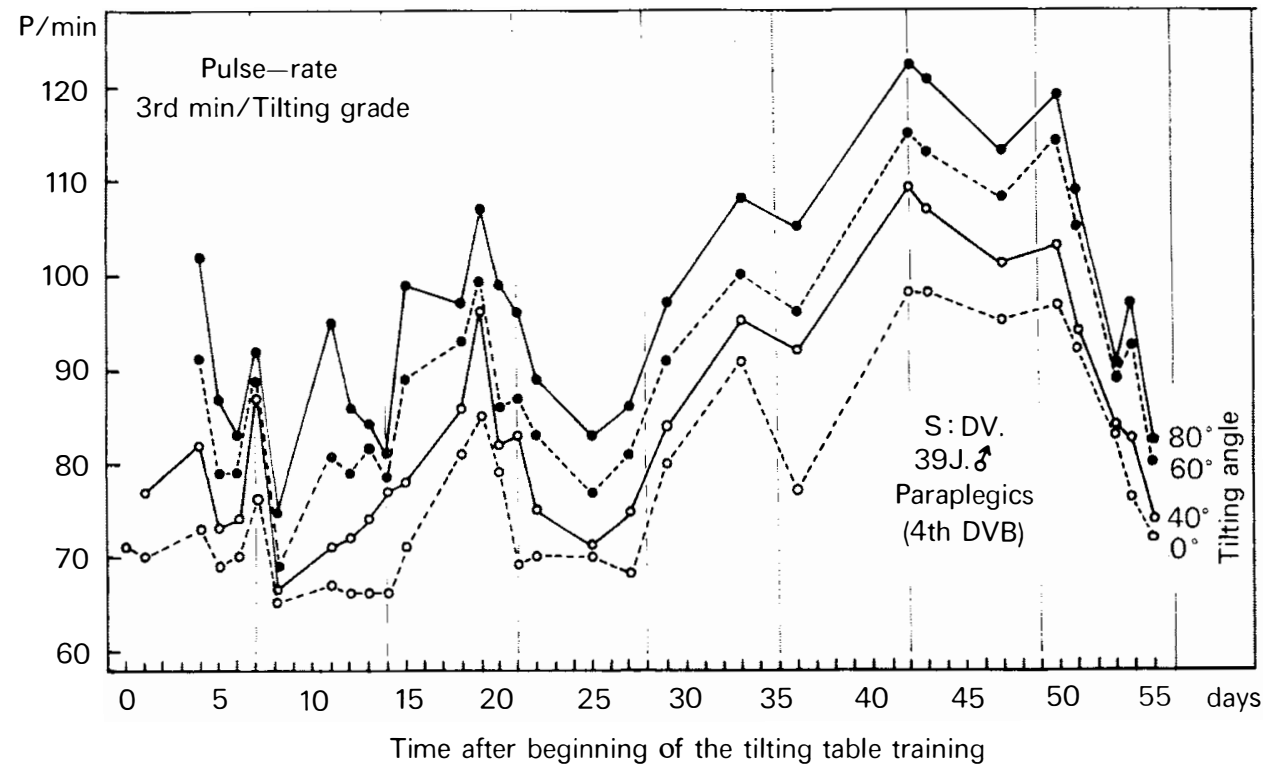

FIG. 5

Course of the absolute pulse-rate of a paraplegic patient with spinal cord injury of the 6th thoracic vertebra during orthostatic tilt-table exercise at various degrees of tilting over a period of 55 days. 
on an uninterrupted long-term observation with objective methods of measuring. At the same time they are the basic condition for an answer to the further question, which is of practical importance, as to in what doses and in what sequence the orthostatic training may lead to optimal success.

\section{SUMMARY}

Results of long-term observations of paraplegics with upper lesions are presented. The circulatory behaviour of patients, completely bedridden for several months, was observed during orthostatic tilt-table exercise over a period of at least 7 weeks. It is not possible to achieve a decisive circulatory stabilisation in paraplegics with upper lesions.

For the most part, there was no improvement in the process of adaptation to varying orthostatic intensity. Much more marked are fluctuations in the ability to adapt to orthostasis, whereby the maximum circulatory lability may not occur until several weeks after the start of therapeutic repositioning to sitting. In practice, these observations point to the need for a sufficiently long period of orthostatic observation of these patients' circulatory system.

\section{RÉSUMÉ}

Examens de coupe longitudinale d'un entraînement orthostatique après des paralysies transversales de la colonne vertébrale.

Les résultats des examens en coupe longitudinale des paralysies transversales de la colonne vertébrale avec grandes lésions, pour lesquelles après plusieurs mois de repos allongé, le comportement de la circulation au cours de l'entraînement "table basculante" orthostatique qui fut suivi pendant au moins 7 semaines sont les suivantes.

Dans son ensemble, une stabilisation de la circulation dans ces paralysies transversales, ne pouvait être atteinte.

Le déroulement de l'adaptation à la charge orthostatique ne montre pas dans ce cas particulier de progrès continus. Les résultats d'adaptation sont plus marqués par des variations précises, où il semble que le sommet de la stabilité de la circulation peut se produire seulement quelques semaines après le commencement du redressement thérapeutique.

Par ce fait, il ressort dans la pratique qu'une surveillance suffisamment longue de la circulation orthostatique et qu'un repos allongé plus long est nécessaire chez ces patients.

\section{ZUSAMMENFASSUNG}

Es werden die Ergebnisse von Längsschnittuntersuchungen an Querschnittsgelähmten mit hohen Läsionen mitgeteilt, bei denen nach mehrmonatiger fester Liegezeit das Kreislaufverhalten beim orthostatischen Kipptischtraining über mindestens 7 Wochen verfolgt wurde.

Insgesamt konnte bei den untersuchten Querschnittsgelähmten mit hohen Läsionen eine deutliche Kreislaufstabilistierung nicht erreicht werden.

Der Adaptationsverlauf an die orthostatische Belastung zeigte im Einzelfall zumeist kein kontinuierliches Fortschreiten; er ist vielmehr durch deutliche Schwankungen der Anpassungsleistung gekennzeichnet, wobei der Höhepunkt der Kreislauflabilität durchaus erst einige Wochen nach Beginn des therapeutischen Aufrichtens eintreten kann. Daraus ergibt sich für die Praxis die Forderung nach einer ausreichend langen orthostatischen Kreislaufüberwachung bei diesen Patienten mit langer Liegezeit. 


\section{REFERENCES}

Engel, P. \& HildebrandT, G. (I973). Long-term spiroergometric studies of paraplegics during the clinical period of rehabilitation, Paraplegia, II, I05-I IO.

Hildebrandt, G. (I962). Biologische Rhythmen und ihre Bedeutung für die Bäder-u. Klimaheilkunde. Schattauer, Stuttgart, 730-785.

HILDEBRANDT, G. (1972). Arbeitsphysiologische Gesichtspunkte zur Rehabilitation Körperbehinderter. Z. Orthop. I I 0, 934-942.

JAEGER-DENAVIT, O. \& GRIOSSIORD, A. (I972). Respiratorische und cardiovakuläre orthostatische Anpassungen bei Paraplegie und Tetraplegie aufgrund von Rückenmarksverletzungen. Abstracts: 6. Intern. Kongr. f. Physik. Med., Barcelona, 6r.

Miller, P. B., Johnson, R. L. \& LAmb, L. E. (I964). Effects of four weeks of absolute bed rest on circulator functions in man. Aerospace Med., 35, I I94-I200.

Rieckert, H. (1970). Die Hämodynamik des venösen Rückflusses aus der unteren Extremität. Arch. Kreislaufforschg. 62, 293-318.

Rieckert, H. (1972). Orthostasesyndrom (Physiologie u. Pathophysiologie). Kurzmonographie Sandoz 6. 